\title{
Formation of diapiric structure in the deformation zone, central Indian Ocean: A model from gravity and seismic reflection data
}

\author{
K S Krishna*, D Gopala Rao and Yu P Neprochnov ${ }^{\dagger}$ \\ National Institute of Oceanography, Dona Paula, Goa 403 004, India. \\ ${ }^{\dagger}$ P.P. Shirshov Institute of Oceanology, 36 Nakhimovsky Prospect, Moscow 117851, Russia. \\ *e-mail: krishna@csnio.ren.nic.in
}

\begin{abstract}
Analyses of bathymetry, gravity and seismic reflection data of the diffusive plate boundary in the central Indian Ocean reveal a new kind of deformed structure besides the well-reported structures of long-wavelength anticlinal basement rises and high-angle reverse faults. The structure (basement trough) has a length of about $150 \mathrm{~km}$ and deepens by up to $1 \mathrm{~km}$ from its regional trend (northward dipping). The basement trough includes a rise at its center with a height of about $1.5 \mathrm{~km}$. The rise is about $10 \mathrm{~km}$ wide with rounded upper surface and bounded by vertical faults. A broad freeair gravity low of about $20 \mathrm{mGal}$ and a local high of $8 \mathrm{mGal}$ in its center are associated with the identified basement trough and rise structure respectively. Seismic results reveal that the horizontal crustal compression prevailing in the diffusive plate boundary might have formed the basement trough possibly in early Pliocene time. Differential loading stresses have been generated from unequal crust/sediment thickness on lower crustal and upper mantle rocks. A thin semi-ductile serpentinite layer existing near the base of the crust that is interpreted to have been formed at mid-ocean ridge and become part of the lithosphere, may have responded to the downward loading stresses generated by the sediments and crustal rocks to inject the serpentinites into the overlying strata to form a classic diapiric structure.
\end{abstract}

\section{Introduction}

The events of unification of Indian and Australian plates in the middle Eocene (Liu et al 1983; Krishna et al 1995), hard continent-continent collision to the north of the Indian shield (Curray et al 1982) and continuous generation of new oceanic lithosphere along the Carlsberg-Central IndianSoutheast Indian Ridges have led to the development of instability within the central Indian Ocean lithosphere. The compressive stresses that accumulated during the course of the instability process reached the failure stage and triggered seismic activity in the middle of the Indo-Australian plate that deformed the upper lithosphere intensively (Weissel et al 1980). The activity's imprints are well documented in both the oceanic basement and the overlying sediments in a wide region in the Central Indian Basin (figure 1) in the form of long-wavelength anticlinal basement rises and high-angle reverse faults (Weissel et al 1980; Geller et al 1983; Neprochnov et al 1988; Bull 1990; Bull et al 1992; Krishna et al 1998, 2001). On the basis of off-ridge earthquake data Royer and Gordon (1997) and Gordon et al (1998) have demarcated the convergent and divergent diffusive plate boundaries in the central Indian Ocean (figure 1).

Bathymetry, gravity and seismic reflection data collected mostly between the Afanasy Nikitin seamount and the Ninetyeast Ridge in the central Indian Ocean are analyzed to map and understand the formation of unreported deformed structures.

Keywords. Diffusive plate boundary; deformation zone; diapiric structure; serpentinized peridotites; crustal structure; differential loading stresses. 


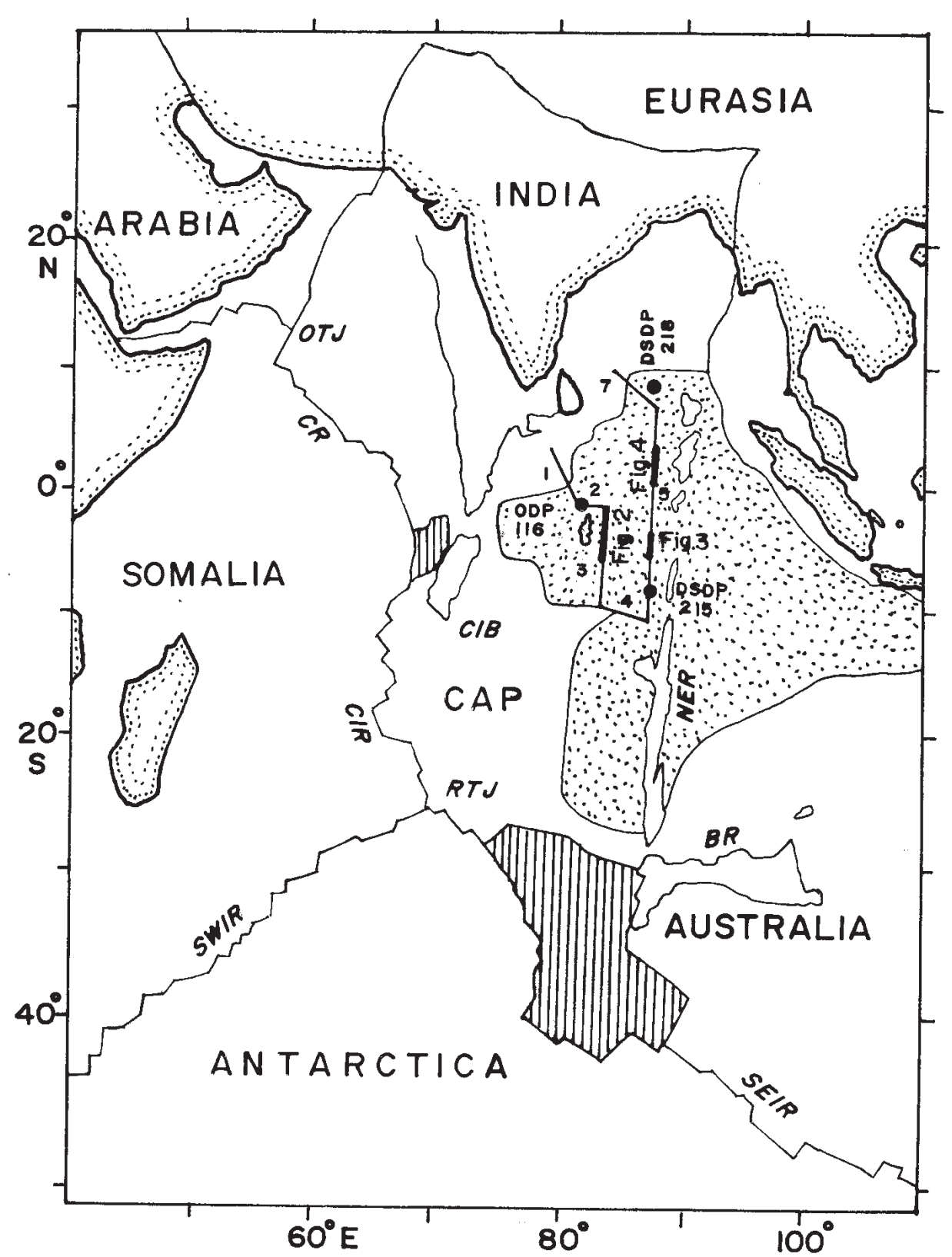

Figure 1. Ship tracks of bathymetry, gravity and seismic reflection profiles in the deformation zone of the central Indian Ocean. Striped and dotted (about the Ninetyeast Ridge) zones are diffuse lithospheric plate boundaries in which divergent and convergent deformations are taking place, respectively (Royer and Gordon 1997; Gordon et al 1998). CAP, RTJ, CIR, SWIR, SEIR, CR, OTJ, NER, and BR represent the Capricon plate, Rodrigues Triple Junction, Central Indian Ridge, Southwest Indian Ridge, Southeast Indian Ridge, Carlsberg Ridge, Owen Triple Junction, Ninetyeast Ridge, and Broken Ridge, respectively.

The objectives of this work are:

- To identify new deformed structures in the light of earlier reported structures,

- to interpret and discuss the probable processes for the formation of the structure and

- to determine the crustal structure beneath the newly identified deformed structure.

\section{Gravity and seismic reflection data}

Bathymetry, gravity, and single-channel seismic reflection data of about 4270-line $\mathrm{km}$ passing through the ODP Leg 116 sites and DSDP Site 215 were acquired in the central Indian Ocean during the 10th cruise (February - March 1995) of A. A. Sidorenko (AS 10). Two long N-S profiles (AS $10-03$ and $10-05$ ) along $83.7^{\circ} \mathrm{E}$ and $87^{\circ} \mathrm{E}$ run within the convergent diffusive plate boundary (figure 1). GPS was used as a navigational aid during the surveys. The gravity data were acquired with Lacoste-Romberg gravimeter with reference base system IGSN - 71. Free-air gravity anomalies were calculated by applying Eotvos correction and normal gravity with reference ellipsoid GRS 67 at the 
observational positions. Seismic data were acquired with GAK in SEG Y format system. A 3 L capacity single airgun was fired at $50 \mathrm{~m}$ interval along the profiles. The data were received by an array of 46 hydrophones in $45 \mathrm{~m}$ long streamer and recorded for a length of $4 \mathrm{~s}$ at $2 \mathrm{~ms}$ sampling interval. Standard processing was carried out onboard the vessel and seismic sections were generated.

\section{Deformed structures in the central Indian Ocean}

Seismic reflection data acquired along two N-S profiles AS 10-03 and 10-05 (figure 1) depict the deformation of oceanic basement, overlying Bengal Fan sediments and some tectonic features. The oceanic crust was deformed in two different structural styles namely: long-wavelength anticlinal basement rises and high-angle reverse faults, which are distributed widely in the central Indian Ocean. The structures were mapped and discussed in terms of morphology, origin, spatial extent, time of deformation, etc. by several investigators (Weissel et al 1980; Geller et al 1983; Neprochnov et al 1988; Bull 1990; Bull and Scrutton 1990; Bull and Scrutton 1992; Chamot-Rooke et al 1993; Krishna et al 1998, 2001; Neprochnov et al 1998). Further to these, a new kind of deformed structure - a rise located in the middle of the basement trough - has been mapped and reported for the first time in this study.

\subsection{Long-wavelength anticlinal basement rises}

Seismic reflection data along profile AS 10-03 show two long-wavelength anticlinal basement rises between latitudes $2^{\circ} \mathrm{S}$ and $5^{\circ} \mathrm{S}$ (figure 2). They are separated by a trough spanning for about $200 \mathrm{~km}$. Relatively older sedimentary layers having late Miocene age (Krishna et al 2001) are exposed on the northern anticlinal basement rise, suggesting that the basement rise was formed at the time of the formation of exposed sediments. Southern rise is carpeted with very thin sediments. It shows recent reactivation of the eastern flank of the Afanasy Nikitin seamount due to deformation process. The rise was initially basement structure (eastern flank) of the Afanasy Nikitin seamount with slight shoaling. Its sides to the north and south exhibit very low gradient. During the late Miocene deformation the basement structure was buckled, faulted and even uplifted to form longwavelength fold structure (figure 2). Some of the lower sedimentary layers follow the basement trend of the structure on its slopes and abut against it. A broad (about $300 \mathrm{~km}$ wavelength) and slight shoaling of the basement structure was observed on profile $\mathrm{AS} 10-05$ at around $3^{\circ} \mathrm{S}$ (Krishna et al 1998, 2001). It represents an anticlinal basement rise with relatively large wavelength and low amplitude. The majority of these basement rises in the deformation zone are trending approximately $70^{\circ} \mathrm{E}$ and terminate at fracture zones (Neprochnov et al 1988; Bull 1990; Neprochnov et al 1998).

\subsection{High-angle reverse faults}

Seismic reflection data shown in figure 3 present a series of tight folds and high-angle reverse faults of $5-20 \mathrm{~km}$. The oceanic basement and a major part of the overlying Bengal Fan sedimentary strata present in an area south of $1^{\circ} \mathrm{S}$ have been faulted and folded severely during the deformation activity that occurred at late Miocene and late Pleistocene (Krishna et al 1998, 2001). The basement has been dislocated vertically by faults up to $1 \mathrm{~km}$ (figure 3). Onlapping of lower sediment layers against a basement rise is seen (figure 3), suggesting its non-deformational origin. Two distinct sedimentary sections above the basement are separated by a boundary. The lower sedimentary section, which is much thicker than the overlying one, follows closely the trend of basement pattern, whereas in the upper section seismic reflectors are near parallel (figure 3). The seismic reflectors near the boundary are onlapping, making the boundary as structural unconformity. The unconformity indicates the time of onset of deformation in the central Indian Ocean. Zones of high-angle reverse faults are widely distributed in the entire deformation area and they have been well studied (Neprochnov et al 1988, 1998; Bull and Scrutton 1990; Krishna et al 1998, 2001).

\subsection{Basement trough and diapiric structure}

The depth to the seafloor along the profile AS 1005 increases towards the south while the depth to the basaltic basement from the seafloor generally increases from south to north except in the vicinity of deformed structures as shown in figures 3 and 4 . In the vicinity of $2.5^{\circ} \mathrm{N}$ the basaltic basement is depressed by about $0.6 \mathrm{~s}$ two-way travel time (TWT) from the regional basement trend (figure 4). The depression covers a distance of about $150 \mathrm{~km}$ and marks a basement trough. A basement rise with steep gradient toward south and relatively low gradient toward north is located almost in the center of the basement trough. The width of the rise is about $10 \mathrm{~km}$ (figures 4,5 and 6 ). The structure rises by up to $1 \mathrm{~s}$ TWT from its base and is flanked by vertical faults. The basement trough and structural rise within it are associated with free-air gravity low of about $20 \mathrm{mGal}$ and a local 


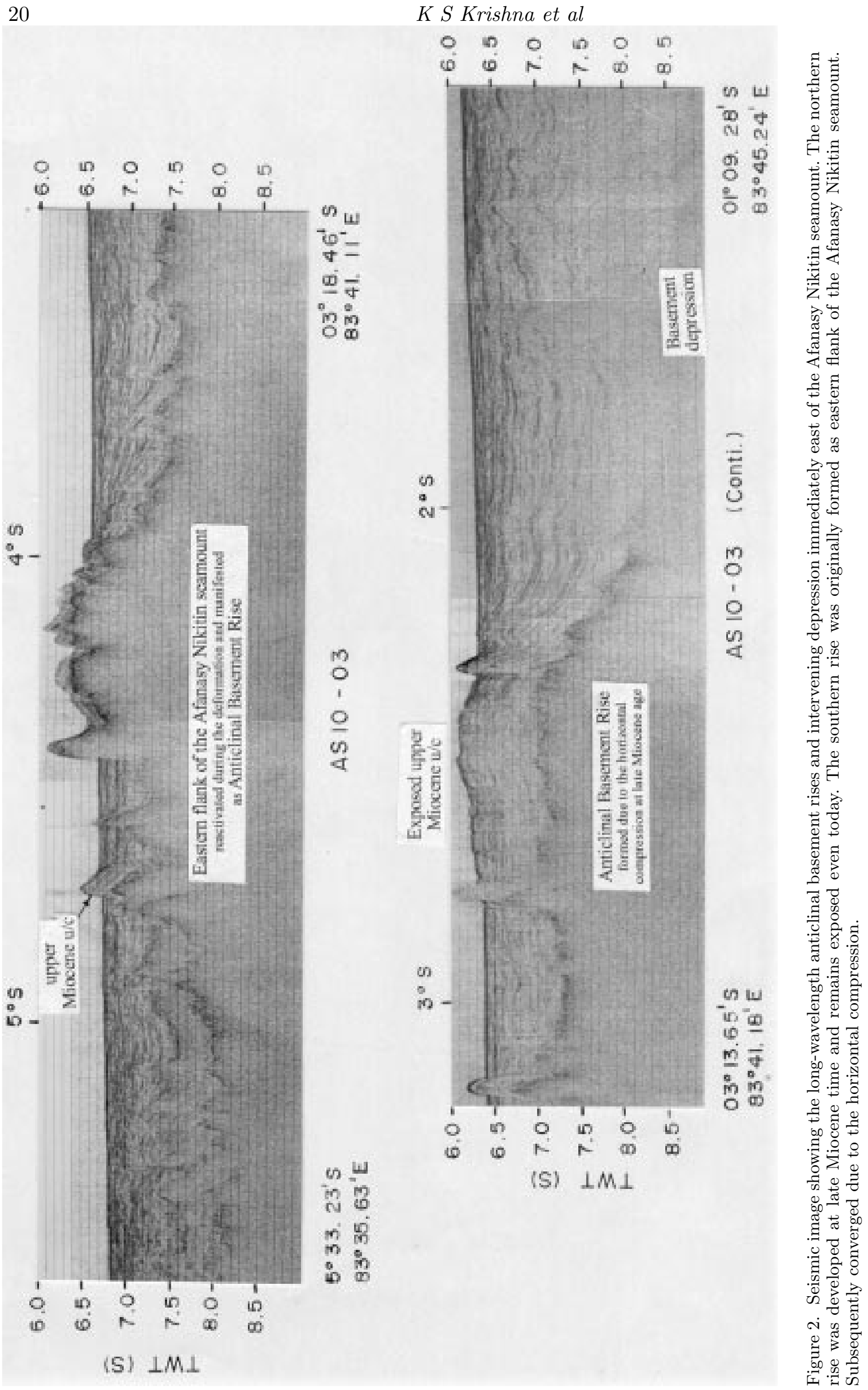




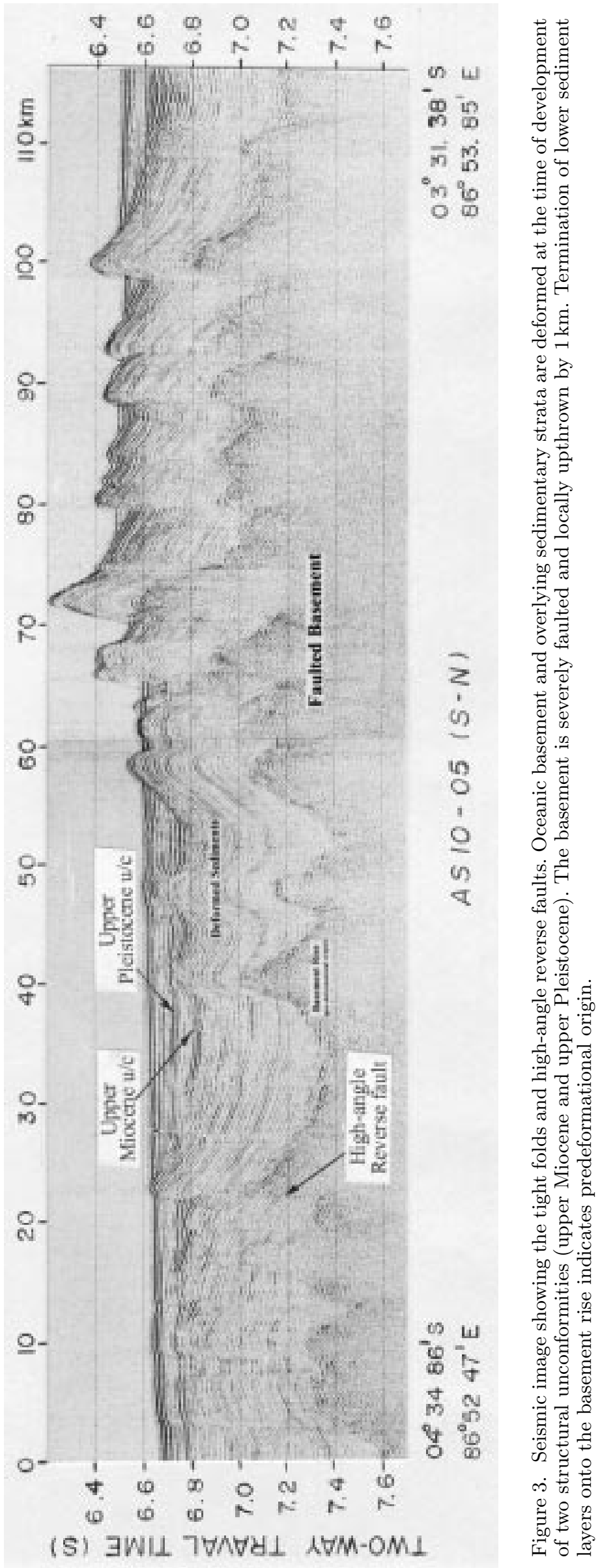


high of $8 \mathrm{mGal}$ respectively (figure 4 ). An interesting point to note here is that the width of the local gravity anomaly $(\sim 40 \mathrm{~km})$ is greater than the actual width of the structural rise observed in the seismic reflection data (figure 4).

In the deformation zone of the central Indian Ocean, a basement trough is observed generally between the long-wavelength anticlinal basement rises. An exception to this, a basement trough with absence of anticlinal rises on either side is observed across $87^{\circ} \mathrm{E}$ between $2^{\circ} \mathrm{N}$ and $3^{\circ} 15^{\prime} \mathrm{N}$ (figure 4). About $1.6 \mathrm{~s}$ TWT thick sediments immediately above the basement follow the trend of the basement trough, suggesting that the trough has developed during the post deposition. While the basement trough was in progress, perhaps after reaching the failure stage, a structural rise was generated almost in the center of the trough (figures 4 and 5). The top of the rise is in a round shape and cut by vertical faults. The structure may possibly represent a diapir consisting of lower crustal rocks.

The sediments are $3.5 \mathrm{~km}$ thick near the diapiric structure. The seismic sequence analyses of the reflection data (figure 6) indicate five major seismic boundaries that are marked on the basis of sediment reflection character, structural unconformities and continuity of the reflector pattern. As the reflection profile AS 10-05 (partly shown in figures 3,4 and 5 ) is at about $600 \mathrm{~km}$ away from the ODP 717-719 drill sites and about $100 \mathrm{~km}$ away from DSDP Site 218, an indirect approach is followed to assign the ages for the identified sequences. The profile in the south runs through the DSDP Site 215 (figure 1), but the results could not be utilized, as the sediments are very thin and localized, hence unable to establish the continuity of the reflectors. Seismic stratigraphic studies of the central Indian Ocean (Krishna et al 2001) have shown that the northeastern part (east of $84^{\circ} \mathrm{E}$ and north of the equator) of the crust is in quasi-continuous deformation since the Pliocene. The identified sequences are compared to the earlier results (Krishna et al 1998, 2001; Neprochnov et al 1998) to assign the ages.

The lower boundary marked as ' $\mathrm{O}$ ' (figure 6) separates the layer of reflection free sediments, lying above the basement, from the section of stratal pattern reflectors. Such boundary was identified in seismic profile that runs along $81^{\circ} 25^{\prime} \mathrm{E}$ longitude through ODP Leg 116 sites (Neprochnov et al 1998) and related its age to the beginning of the Oligocene. Hence the early Oligocene age is assigned to the boundary and interpreted it as the time of initiation of turbidite sedimentation in the Bengal Fan. The boundaries $A$ and $B$ are mapped on the basis of correlation to the upper Miocene and upper Pleistocene unconformities, which were identified with confidence at around $4^{\circ} \mathrm{S}$ on the same profile AS 10-05 (Krishna et al 1998, 2001). The boundary AA is separating the two sedimentary units (figure 6). In the lower sedimentary unit, reflectors are parallel to each other and follow the trend of the trough and rise of the basaltic basement, whereas the upper unit has less influence of the basement structures. Onlaps of sediment reflectors on boundary AA is clearly observed on the diapiric structure. These results reveal that the boundary is an unconformity, suggesting the initial development of basement trough and rise soon after formation of the boundary. Earlier Krishna et al $(1998,2001)$ have reported the presence of lower Pliocene unconformity in the area north of $1^{\circ} \mathrm{S}$. Keeping the spatial deformation activity in view, the early Pliocene age is assigned to the boundary AA (figure 6). The structures (trough and rise) had developed at early Pliocene age and then slowly grown-up until recent time. Many of the highangle faults are extending from basement to the sediments, younger than the late Pleistocene age, but their offsets gradually decrease from basement to seafloor (figure 6). Similarly, amplitudes of the folds at basement and in the overlying sediments also are decreasing. This is in contrast to the nearly constant offsets along the faults and amplitudes of the folds observed in the area south of the equator (Leg 116 Shipboard Scientific Party 1987; Bull and Scrutton 1990; Krishna et al 1998; Neprochnov et al 1998). The varied offsets and amplitudes perhaps reflect variations in mechanical strength of the sediments marking weaker in the north in comparison to south of the equator. Lateral variations in velocities of the sediments can also contribute to such variations.

\section{Formation of diapiric structure}

The horizontal compression prevailing in the central Indian Ocean appears to have created the basement trough without anticlinal rises on either side around early Pliocene age. Unequal loading stresses were generated within the basement trough due to excess thickness of sediments. The stresses were generally contributed to instability to form a diapiric structure.

Hess (1955); Lobkovsky et al (1986) and Lobkovsky and Kerchman (1991) have suggested the possible presence of serpentinite layer below the base of the crust near the mid-ocean ridge and become part of the lithosphere. Subsequently the lithosphere moves away as one entity due to the spreading activity. According to the twolevel plate tectonic concept (Lobkovsky and Kerchman 1991), the semi-ductile serpentinite layer plays an important role in a specific geological setting (hard continent-continent collision) of a 


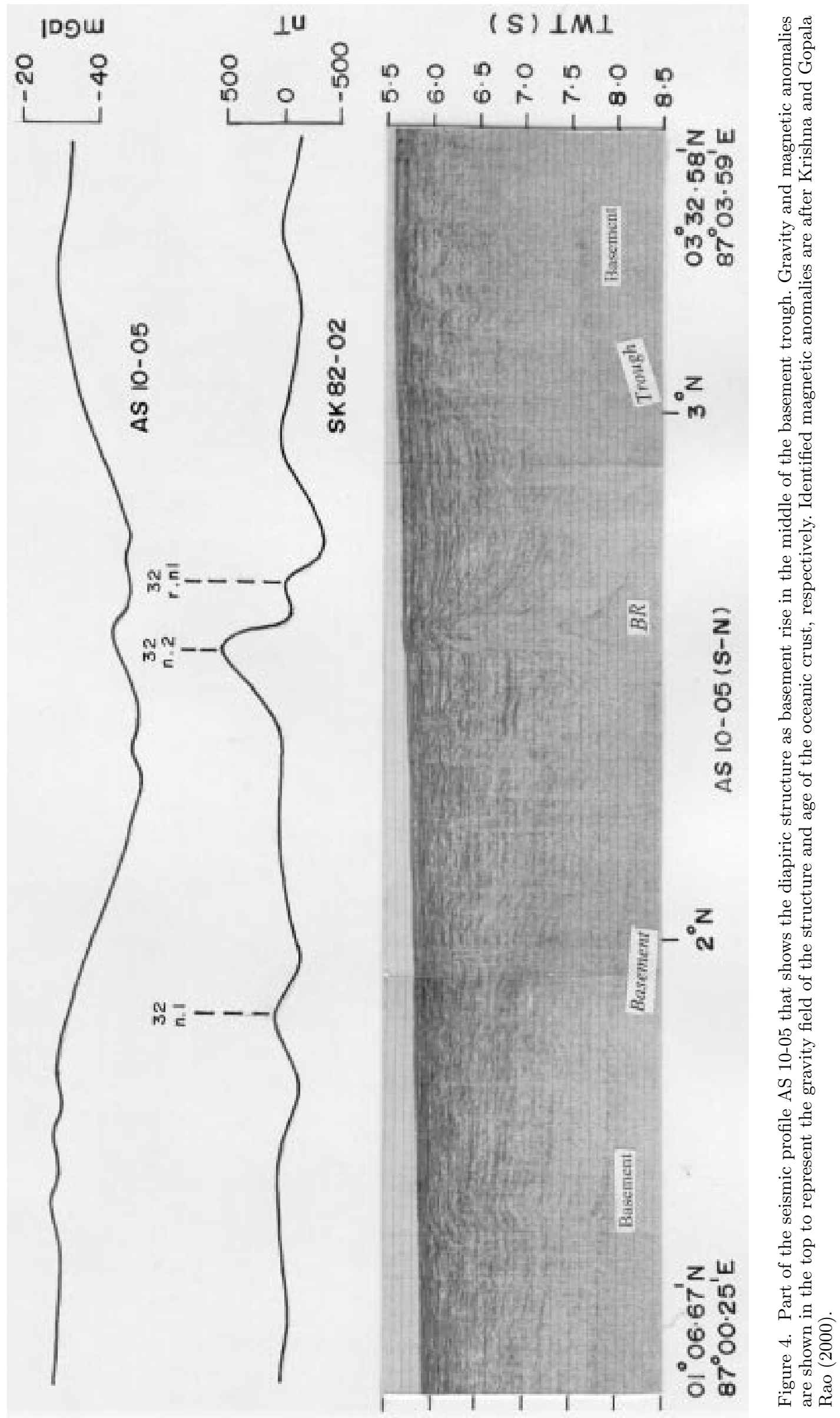




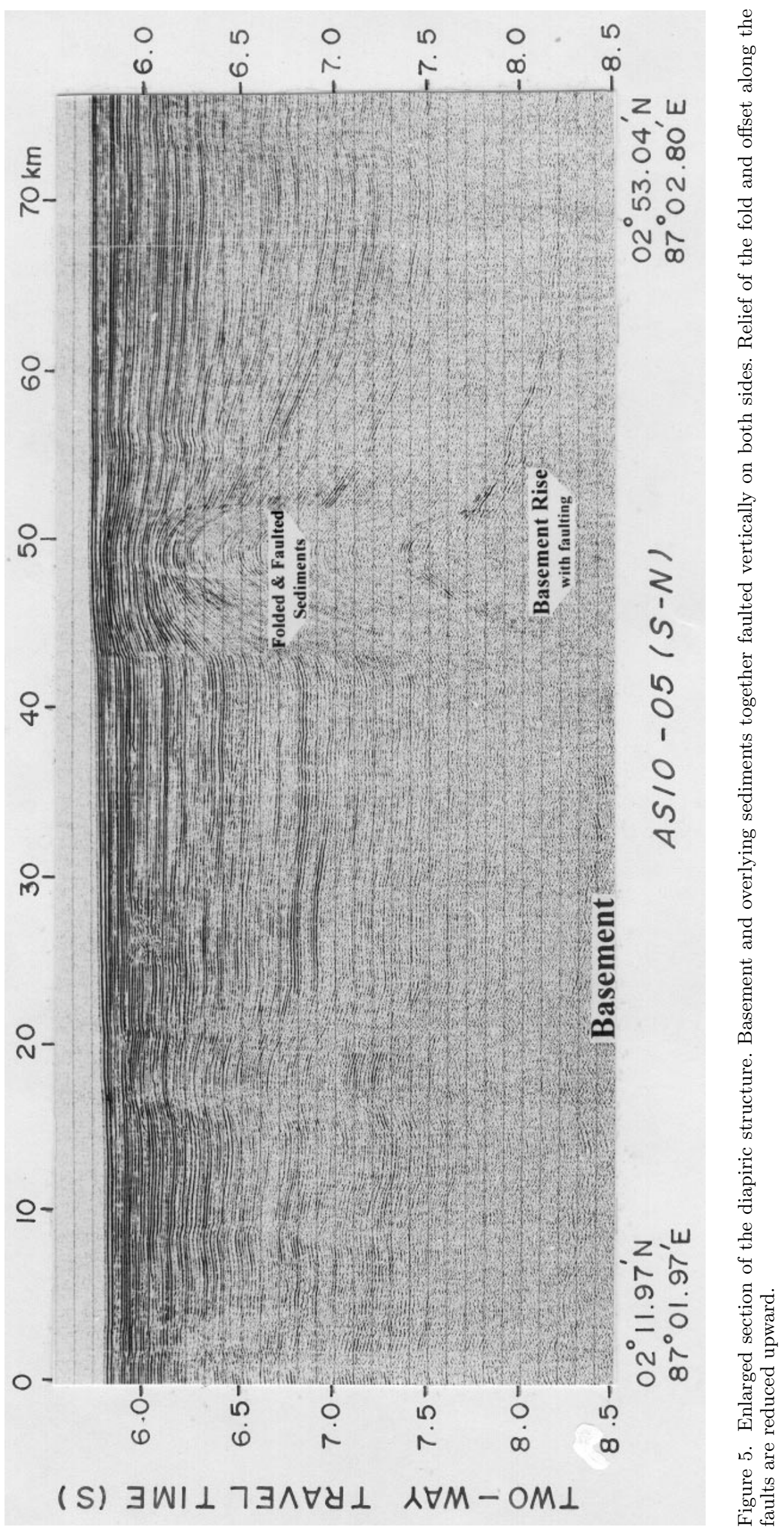




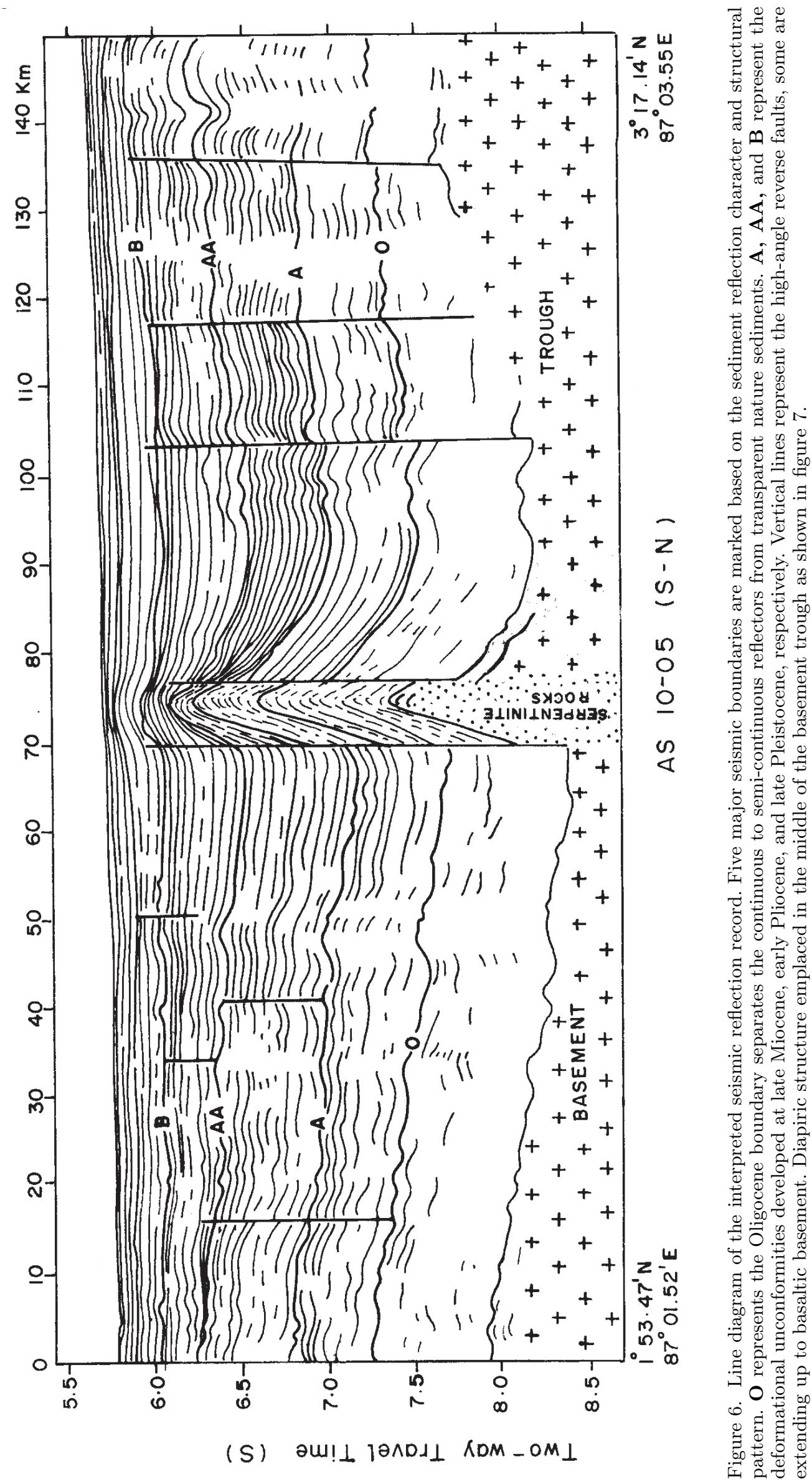


lithospheric plate and allows differential motions within the lithosphere. The Indian plate has such geological setting and becomes a candidate for testing the role of serpentinite layer particularly for determining the vertical extent of the deformation of the lithosphere.

It has been well observed at several sites in the Central Indian Basin that unusual velocities ranging from 7.2 to $7.7 \mathrm{~km} / \mathrm{s}$ characterize the deeper structure of layer 3. Leger et al (1987) and Leger and Louden (1990) have found high velocities (7.2 to $7.5 \mathrm{~km} / \mathrm{s}$ ) in the Central Indian Basin and concluded that they are either unusually high velocities in the mid-crust with an undetected Moho or unusually low velocity mantle with a thin crust. Similarly Curray et al (1982) and Neprochnov et al $(1988,1998)$ have determined the higher velocities at the base of layer 3 at several sites in the Central Indian Basin. Two seismic refraction stations located near the diapiric structure discussed in this paper display the higher velocities (7.6 to $7.7 \mathrm{~km} / \mathrm{s}$ ) in the lower crust (Curray et al 1982). Louden (1995) has observed a low velocity zone $(6.5$ to $6.8 \mathrm{~km} / \mathrm{s})$ within the high velocity lower crust of layer $3 \mathrm{~B}$ and attributed its origin to serpentinization of olivine clasts within the gabbro. These higher velocities near the base of layer 3 are indicative of serpentinized peridotites (Li Pichon et al 1972). It appears there is enough evidence for existence of serpentinized peridotites as a basal layer at several locations in the Central Indian Basin. The epicenters of the earthquakes in the Central Indian Basin are mostly of the shallow type lying in the lower crust and upper mantle (Bergman and Solomon 1985; Levchenko 1989), indicating that there is considerable seismic activity at the base of the crust.

In the Central Indian Basin the serpentinite layer, lying below the base of the crust, facilitates differential motions between the crust and the mantle part of the lithosphere (Lobkovsky et al 1986; Lobkovsky and Kerchman 1991). These motions appear to facilitate the crust to deform more intensively than that in the upper mantle, which are controlled by the intervening semiductile serpentinite layer. In general the serpentinites beneath the basement trough may move laterally depending upon the sediment and crustal rocks load for storing beneath the rises, leading to the thickening of the crust under the anticlinal basement rises compared to that under the basement troughs. Leger and Louden (1990) have, in fact, reported the increase of about $1.7 \mathrm{~km}$ crustal thickness under the rise relative to that under the adjacent trough. In case of basement troughs alone, there was no scope for the serpentinites to move laterally beneath it. As the trough develops further, the downward loading stresses will increase on the serpentinites. As a result of unequal loading by the sediment and crustal rocks in the trough, the serpentinites might have intruded through the overlying strata forming a serpentinite diapiric structure.

\section{Gravity model of the diapiric structure}

Free-air gravity anomalies across the basement trough and diapiric structure are modeled with the consideration of seismic constraints such as sediment thickness, basement trend (figure 4), general thickness of layer 2, layer 3, and proposed serpentinite layer (Curray et al 1982; Lobkovsky et al 1986; Leger et al 1987; Neprochnov et al 1988; Leger and Louden 1990; Louden 1995; Neprochnov et al 1998). Densities ranging from 1.03 to $3.35 \mathrm{gm} / \mathrm{cc}$ are used for water column, sediments, various crustal layers, and mantle rocks. Serpentinite rise in the form of diapiric structure is assumed at various levels within the crust for model studies. Major portion of the anomaly is generated by topography of various crustal layers and presence of serpentinites as a basal layer. Minor adjustments are made by placing the serpentinites at different levels and changing densities within the range of individual rock material. A reasonable good fit is achieved between observed and calculated gravity anomalies when the serpentinite structure is extending up to the basement level.

Gravity anomalies are calculated for three crustal models, assuming

- all the crustal layers including the Moho follow the trend of the basaltic basement,

- crustal layers and serpentinite layer follow the trend of the basement and flat Moho, and

- serpentinites piercing through the crustal layers up to the basement.

In all three models we could get reasonably goodfit between observed and computed free-air gravity anomalies. The effect of small density contrast $(0.1 \mathrm{gm} / \mathrm{cc})$ between crustal layers and diapir material could not be seen visibly in the computed gravity anomaly (figure 7) as that is controlled in major part by the basement topography. An emplacement of serpentinite rocks in the form of diapiric structure near the basement is the preferred model (third model) to explain the geophysical observations and crustal dynamics. The model derived from gravity and seismic reflection data is shown in figure 7 . The presence of earthquakes surrounding the basement trough-diapiric structure (Gutenberg and Richter 1965; Dziewonski et al 1984) is also supporting the dynamic process of the region. A local gravity high within the broad gravity low is generated by diapiric structure and partly by basement trend (figure 7). 

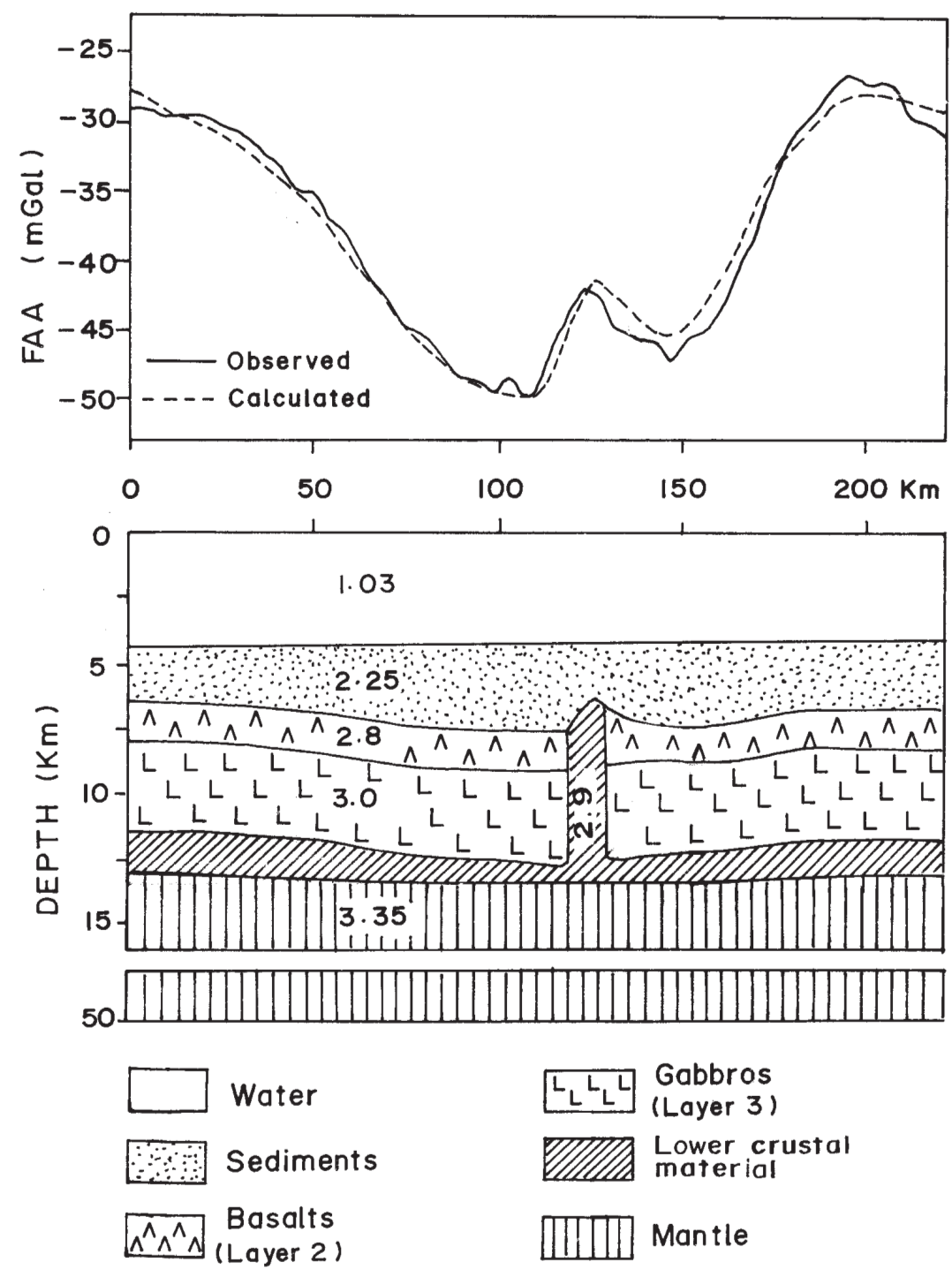

Figure 7. Two-dimensional gravity model and interpreted crustal structure. Sedimentary layer and top of basaltic layer (layer $2 \mathrm{~A}$ ) are taken from the seismic reflection results shown in figure 4 . Deeper seismic layers $2 \mathrm{~B}$ and 3 are considered from the published seismic refraction results of this region. The numbers in crustal model indicate the densities (gm/cc).

\section{Conclusion}

A new deformed structure in the form of basement trough associated with a diapir is identified in the deformation zone of the central Indian Ocean. The diapir is about $10 \mathrm{~km}$ wide and $1.5 \mathrm{~km}$ high from the adjacent basement. It is lying in the middle of the $150 \mathrm{~km}$ long basement trough. Horizontal crustal compression might have resulted in the basement trough in early Pliocene time. Differential loading by the sediment and crustal rocks within the trough may have resulted in diapiric structure near the oceanic basement.

\section{Acknowledgements}

The work was carried out under ILTP project B-2.25, supported by DST, New Delhi and RAS,
Moscow. We are indebted to L I Lobkovsky, Institute of Oceanology, Moscow for his discussions and are grateful to E Desa, Director, NIO for his encouragement. Authors are thankful to Jon Bull and an anonymous reviewer, whose comments and suggestions have helped to improve the manuscript. This is NIO contribution number 3718 .

\section{References}

Bergman E A and Solomon S C 1985 Earthquake source mechanisms from body waveform inversion and intraplate tectonics in the northern Indian Ocean; Phys. Earth Planet. Inter. 40 1-23

Bull J M 1990 Structural style of intraplate deformation, Central Indian Ocean Basin: evidence for the role of fracture zones; Tectonophys. 184 213-228 
Bull J M and Scrutton R A 1990 Fault reactivation in the Central Indian Ocean and the rheology of oceanic lithosphere; Nature 344 855-858

Bull J M, Martinod J and Davy P H 1992 Buckling of the oceanic lithosphere from geophysical data and experiments; Tectonics 11 537-548

Bull J M and Scrutton R A 1992 Seismic reflection images of intraplate deformation, Central Indian Ocean, and their tectonic significance; J. Geol. Soc. London 149 955-966

Chamot-Rooke N, Jestin F, de Voogd B and Phedre Working Group 1993 Intraplate shortening in the central Indian Ocean determined from a 2100-km-long northsouth deep seismic reflection profile; Geology 21 10431046

Curray J R, Emmel F J, Moore D G and Russel W R 1982 Structure, tectonics, and geological history of the northeastern Indian Ocean; In: The Ocean Basins and Margins, The Indian Ocean, vol. 6, (eds) A E Nairn and F G Stheli, (New York: Plenum) pp. 399-450

Dziewonski A M, Franzen J E and Woodhouse J H 1984 Centroid moment tensor solutions for July-September 1983; Phys. Earth Planet. Inter. 34 1-8

Geller C A, Weissel J K and Anderson R N 1983 Heat transfer and intraplate deformation in the Central Indian Ocean; J. Geophys. Res. 88 1018-1032

Gordon R G, DeMetes C and Royer J-Y 1998 Evidence for long-term diffuse deformation of the lithosphere of the equatorial Indian Ocean; Nature 395 370-374

Gutenberg B and Richter C F 1965 Seismicity of the Earth and Associated Phenomena; (New York: Hafner)

Hess H H 1955 Serpentinites, orogeny and epeirogeny; Geol. Soc. Am. Spec. paper 62 391-408

Krishna K S, Gopala Rao D, Ramana M V, Subrahmanyam V, Sarma K V L N S, Pilipenko A I, Shcherbakov V S and Radhakrishna Murthy I V 1995 Tectonic model for the evolution of oceanic crust in the northeastern Indian Ocean from the late Cretaceous to the early Tertiary; $J$. Geophys. Res. 100 20011-20024

Krishna K S, Ramana M V, Gopala Rao D, Murthy K S R, Malleswara Rao M M, Subrahmanyam V and Sarma K V L N S 1998 Periodic deformation of oceanic crust in the central Indian Ocean; J. Geophys. Res. 103 17859-17875

Krishna K S and Gopala Rao D 2000 Abandoned Paleocene spreading center in the northeastern Indian Ocean: evidence from magnetic and seismic reflection data; Mar. Geol. 162 215-224
Krishna K S, Bull J M and Scrutton R A 2001 Evidence for multi-phase folding of the central Indian Ocean lithosphere; Geology 29 715-718

Leg 116 Shipboard Scientific Party 1987 Collisions in the Indian Ocean; Nature 330 519-521

Leger G T, Louden K E, Forsyth D M and Weissel J K 1987 Crustal structure and faulting in the intraplate deformation region, Central Indian Ocean Basin; Trans. Am. Geophys. Union 68 pp. 1484

Leger G T and Louden K E 1990 Seismic refraction measurements in the Central Indian Basin: evidences for crustal thickening related to intraplate deformation; Proc. ODP Sci. Results 116 291-309

Levchenko O V 1989 Tectonic aspects of intraplate seismicity in the northeastern Indian Ocean; Tectonophys. $\mathbf{1 7 0}$ $125-139$

Li Pichon X, Francheteau J and Bonnin J 1972 Plate tectonics; J. R. Astr. Soc. 26 515-535

Liu C S, Curray J R and McDonald J M 1983 New constraints on the tectonic evolution of the Eastern Indian Ocean; Earth Planet. Sci. Lett. 65 331-342

Lobkovsky L I, Nikolaevsky V N and Karakin A V 1986 Geological and geophysical consequences of ocean lithosphere serpentinisation; Soc. Nat. Philos. Moscow Bull. Sect. Geol. 61 3-12 (in Russian)

Lobkovsky L I and Kerchman V I 1991 A two-level concept of plate tectonics: application to geodynamics; Tectonophys. 199 343-374

Louden K E 1995 Variations in crustal structure related to intraplate deformation: evidence from seismic refraction and gravity profiles in the Central Indian Basin; Geophys. J. Int. $120375-392$

Neprochnov Yu P, Levchenko O V, Merklin L R and Sedov V V 1988 The structure and tectonics of the intraplate deformation area in the Indian Ocean; Tectonophys. 156 $89-106$

Neprochnov Yu P, Gopala Rao D, Murthy K S R and Subrahmanyam C 1998 Intraplate deformation in the Central Indian Ocean Basin; Geol. Soc. India Memoir 39 Bangalore pp. $1-250$

Royer J-Y and Gordon R G 1997 The motion and boundary between the Capricon and Australian plates; Science $\mathbf{2 7 7}$ $1268-1274$

Weissel J K, Anderson R N and Geller C A 1980 Deformation of the Indo-Australian plate; Nature 287 284-291 